\title{
Research and Developments in Thin-Film Silicon Photovoltaics
}

\author{
M. Despeisse*a, C. Ballifi, A. Feltrin ${ }^{\mathrm{a}}$, F. Meillaud, , S. Fay ${ }^{\mathrm{a}}$, F-J. Haug ${ }^{\mathrm{a}}$, D. Dominéa , M. Python ${ }^{\mathrm{a}}$, T. \\ Soderstrom ${ }^{\mathrm{a}}$, P. Buehlmann ${ }^{\mathrm{a}}$, G. Bugnon ${ }^{\mathrm{a}}$. \\ ${ }^{a}$ Ecole Polytechnique Fédérale de Lausanne (EPFL), Institute of Microengineering (IMT), \\ Photovoltaics and thin-film electronics laboratory, Breguet 2, CH-2000 Neuchâtel, Switzerland
}

\begin{abstract}
The increasing demand for photovoltaic devices and the associated crystalline silicon feedstock demand scenario have led in the past years to the fast growth of the thin film silicon industry. The high potential for cost reduction and the suitability for building integration have initiated both industrial and research laboratories dynamisms for amorphous silicon and micro-crystalline silicon based photovoltaic technologies. The recent progress towards higher efficiencies thin film silicon solar cells obtained at the IMT-EPFL in Neuchatel in small-area laboratory and semi-large-area industrial Plasma Enhanced Chemical Vapor Deposition (PE-CVD) systems are reviewed. Advanced light trapping schemes are fundamental to reach high conversion efficiency and the potential of advanced Transparent Conductive Oxides (TCO) is presented, together with issues associated to the impact of the substrate morphology onto the growth of the silicon films. The recent improvements realized in amorphous-microcrystalline tandem solar cells on glass substrate are then presented, and the latest results on $1 \mathrm{~cm}^{2}$ cells are reported with up to $13.3 \%$ initial efficiency for small-area reactors and up to $12.3 \%$ initial for large-area industrial reactors. Finally, the different strategies to reach an improved light confinement in a thin film solar cell deposited on a flexible substrate are discussed, with the incorporation of asymmetric intermediate reflectors. Results of micromorph solar cells in the n-i-p configuration with up to $9.8 \%$ stabilized efficiency are reported.
\end{abstract}

Keywords: Thin-Film Silicon, Photovoltaics, Amorphous Silicon, Light-Trapping

\section{INTRODUCTION}

The strong needs of society for improved sustainable energy sources on a long time scale basis have initiated in the past years a fast growth of solar panels production (roughly estimated to $7.9 \mathrm{GW}$ for the year 2008 [1]). Photovoltaic modules have to be the source for an ever increasing fraction of the global energy mix in the future, therefore requiring very large scale development and cost reduction of manufacturing (below 1 dollar/Wp to reach grid-parity as already realized by the company FirstSolar with thin film CdTe solar modules [2]). Thin-Film silicon photovoltaic is a promising technology

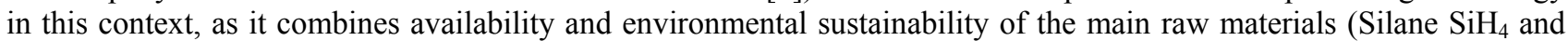
hydrogen $\mathrm{H}_{2}$ ). The deposition processes of thin film silicon (principally Plasma Enhanced Chemical Vapor Deposition, PECVD) are compatible with mass-production processes on rigid and on flexible large-area substrates, allowing for immediate costs reduction potential and for lower energy payback time than for typical wafer-based PV technologies [3], with additional high potential for building integration (BIPV).

These different advantages have triggered a high industrial dynamism in thin film silicon PV in the past 5 years with the development of established equipment providers [4]-[5] and with the high increase of thin film silicon modules manufacturers. The remaining technology constraint which has hindered a larger market share is the limited conversion efficiency which can be attained. The conversion efficiency of hydrogenated amorphous silicon decreases after light exposure (Staebler-Wronski effect [6]) until it reaches equilibrium states; and the actual highest stable efficiencies of a$\mathrm{Si}: \mathrm{H}$ single junction solar cells achieved so far in research institutes is of $9.5 \%$ [7]. Hydrogenated microcrystalline silicon ( $\mu \mathrm{C}$-Si:H), deposited with similar equipments as for a-Si:H, exhibits an indirect bandgap of about $1.1 \mathrm{eV}$, leading to lower open-circuit voltage values but also to enhanced optical absorption in the near infra-red part of the solar spectrum. The electronic transport properties are improved in $\mu \mathrm{C}-\mathrm{Si}: \mathrm{H}$ in comparison to a-Si:H so that thicker absorber intrinsic layers can be used (up to few microns) to obtain sufficient photo-generation, compensating the indirect property

Thin Film Solar Technology, edited by Alan E. Delahoy, Louay A. Eldada, Proc. of SPIE Vol. 7409, 74090B · @ 2009 SPIE · CCC code: 0277-786X/09/\$18 - doi: 10.1117/12.826232 
of the band-gap, and therefore leading to increased short circuit current. The best $1 \mathrm{~cm}^{2}$ single-junction $\mu \mathrm{C}-\mathrm{Si}: \mathrm{H}$ deposited in research institutes attain conversion efficiencies in the order of $10 \%[8,9]$ with no or low degradation of performance under light soaking ( 0 to $10 \%$ of relative degradation) [9].

In order to increase further thin film silicon solar cells efficiencies above $10 \%$, multi-junctions devices have to be used. The advances in the development of micromorph tandem cells, first introduced at the IMT of Neuchatel [10], are reviewed here. This double-junction solar cell consists of a serial optical and electrical connection of an a-Si:H and of a $\mu \mathrm{C}$-Si:H cell, the top cell absorbing photons in the visible part of the spectrum while the bottom cell absorbs red and infrared photons, allowing for improved overall conversion efficiencies, as stable efficiencies up to $11.7 \%$ for $1 \mathrm{~cm}^{2}$ micromorph cells were already demonstrated [11]. A schematic and a cross section image of such solar cell deposited on a glass substrate (in the p-i-n sequence) are shown in Figure 1. The micromorph thin film silicon solar cells developed at the IMT-EPFL are grown by very high frequency plasma enhanced chemical deposition (VHF PECVD) [12], at temperatures ranging from $160{ }^{\circ} \mathrm{C}$ to $250{ }^{\circ} \mathrm{C}$, and from a gas mixture of hydrogen $\left(\mathrm{H}_{2}\right)$ and silane $\left(\mathrm{SiH}_{4}\right)$, ), phosphine $\left(\mathrm{PH}_{3}\right)$ and tri-methyl-boron $\left(\mathrm{B}\left(\mathrm{CH}_{3}\right)_{3}, \mathrm{TMB}\right)$ being used as doping gases.

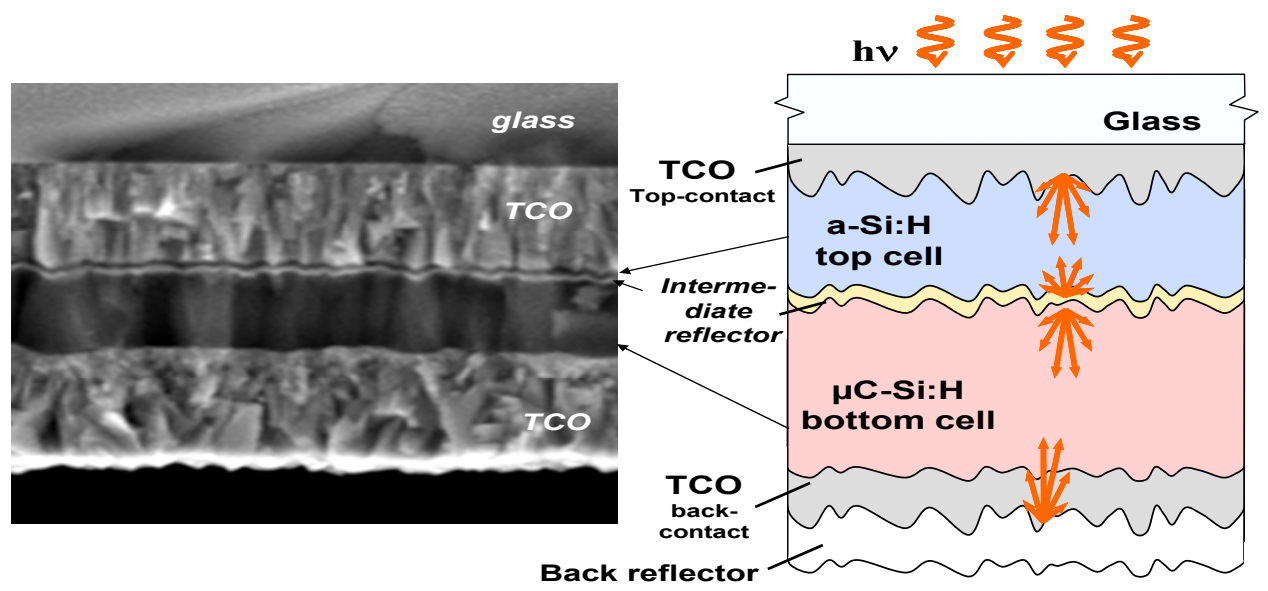

Fig. 1. Left: Scanning Electron Microscope image of the cross section of a micromorph solar cell in the p-i-n configuration with rough Zinc Oxide Transparent Conductive Oxide and intermediate reflector. Right: Corresponding schematic cross section of a micromorph solar cell.

In order to achieve higher efficiency thin film silicon solar cells, light scattering at textured interfaces has become a decisive feature. It allows using thinner absorber layers as the scattering enhances the effective light path in the absorbing film. While this is certainly considerably important for production throughput and for cost reduction, light trapping is also mandatory because of inherent material properties; in case of a-Si:H, the impact of light induced degradation can be reduced in thinner films, while in $\mu \mathrm{C}-\mathrm{Si}: \mathrm{H}$ it can, to some extent, compensate the low absorption of the indirect band-gap. Light scattering is typically achieved at surface textures of the substrate or of the electric contact layer that precedes the silicon deposition [13].

In the superstrate $\mathrm{p}-\mathrm{i}-\mathrm{n}$ sequence, the solar cell front side is the glass substrate on which is grown a Tansparent Conductive Oxide (TCO) which has to exhibit sufficient roughness to increase the optical path of the incoming photons into the solar cell thanks to increased optical diffusion. Results obtained at the IMT-EPFL in Neuchatel with TCO made of conductive Zinc Oxide ( $\mathrm{ZnO}$ ) grown by Low Pressure Chemical Vapor Deposition (LPCVD) are reviewed in section 2 together with studies of the impact on the optical and electrical properties of different surface morphologies. Intermediate reflectors between the a-Si:H and the $\mu \mathrm{C}-\mathrm{Si}: \mathrm{H}$ cells also permit to increase the current generated in the top a-Si:H cell, allowing for reduced thickness of the cell and for decreased light induced degradation. The intermediate reflectors developed at the IMT-EPFL are presented in section 3 with their implementation in micromorph solar cells and their interplay with the TCO front contact roughness.

In substrate n-i-p devices for which the flexible coated substrate corresponds to the solar cell back side, similar concepts can be followed for achieving higher light confinement by texturing the metallic back contacts, e.g. the well known 
surface roughening of silver when it is grown on heated substrates [14]. The substrate surface can also be textured, and finally intermediate reflectors have to be used to optimize the solar cell light confinement. The developments of n-i-p thin film silicon solar cells at the IMT-EPFL with adapted substrate morphology and asymmetric intermediate reflector are presented in section 4 .

\section{ADVANCED TCO POTENTIAL AND ISSUES}

\subsection{LP-CVD ZnO for enhanced light trapping}

In thin film silicon solar cells, the front TCO has to exhibit high transparency in the useful spectral range to minimize optical losses by absorption (and/or by reflection), and to have sufficient conductivity to limit the series resistance of the cell. In the p-i-n configuration, the front TCO has also to show sufficient surface roughness (typical rms values between $50 \mathrm{~nm}$ and $200 \mathrm{~nm}$ ) to optimize light confinement in the thin cell, by reducing reflections at the TCO/p-layer interface thanks to refractive index grading and by increasing the optical path of the incoming photons into the solar cell thanks to increased optical diffusion. In practice, Zinc Oxide $(\mathrm{ZnO})$ or fluorine-doped tin oxide ( $\mathrm{SnO}$ :F) are widely used for p-i-n thin film silicon solar cells. The $\mathrm{ZnO}$ is typically deposited either by sputtering [15] or by LPCVD [16-17], with respectively aluminum and diborane usual dopants. The surface morphology then differs depending on the deposition process, as the sputtered $\mathrm{ZnO}$ is flat as-grown and needs a subsequent treatment (generally by wet etching) to increase its roughness. On the other hand, the $\mathrm{ZnO}$ is rough as-grown via LPCVD, with a wurtzite crystalline structure and a pyramidal growth along the (110) axis [17] as it can be seen from the scanning electron micrographs shown in Figure 2 of the surface of $1.8 \mu \mathrm{m}$ and $4.5 \mu \mathrm{m}$ thick LP-CVD ZnO layers deposited at the IMT-EPFL. This LP-CVD deposition technique has the important advantage of being easily transferrable to industrial depositions on areas larger than $1 \mathrm{~m}^{2}$, as already demonstrated and sold by the company Oerlikon Solar [18].

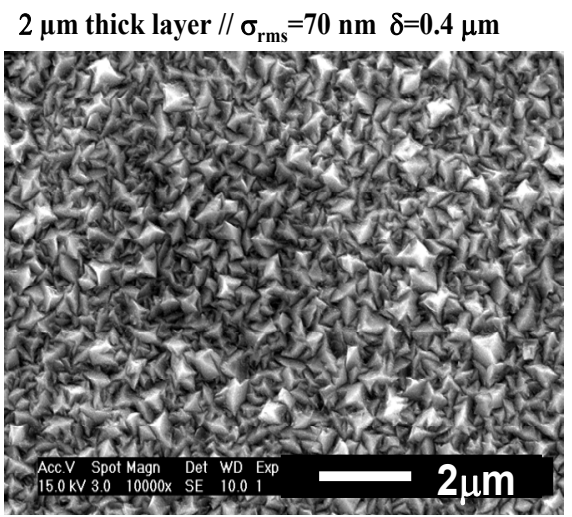

Type A

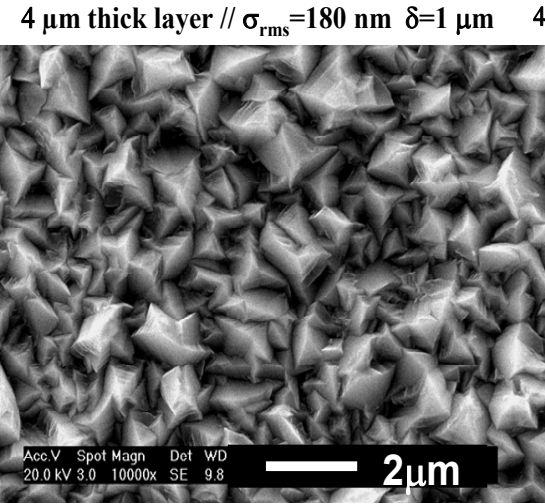

Type C

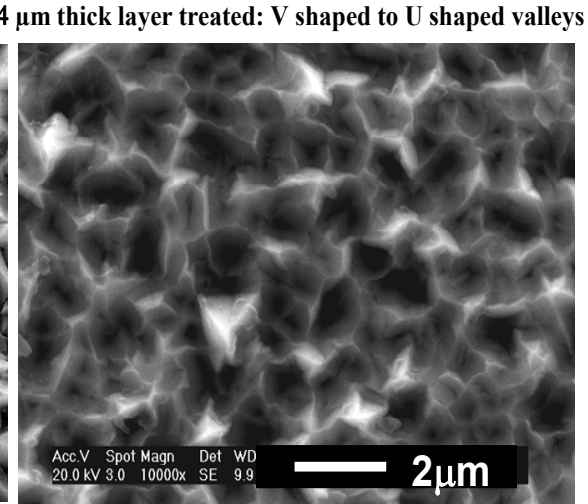

Type C - treated

Fig. 2. Left: SEM image of the surface of a $2 \mu \mathrm{m}$ thick LP-CVD ZnO (type-A), with pyramidal features with a typical size of $400 \mathrm{~nm}$ and $\mathrm{rms}$ roughness of $70 \mathrm{~nm}$. Center: SEM image of the surface of a $4 \mu \mathrm{m}$ thick LP-CVD ZnO (type-C), with pyramidal features with a typical size of $1 \mu \mathrm{m}$ and rms roughness of $180 \mathrm{~nm}$. Right: SEM image of type-C $\mathrm{ZnO}$ with additional surface treatment to smooth out the V shaped valleys to U shaped valleys [17].

For hydrogenated amorphous silicon solar cells, the light confinement is needed in the spectral range of $500 \mathrm{~nm}$ to $800 \mathrm{~nm}$ to allow the development of thinner cells while keeping sufficient short circuit current density, therefore leading to improved stable efficiency of the cell thanks to the reduced thickness. The LPCVD ZnO texture optimized at the IMTEPFL for amorphous silicon is shown in Figure 2 left (type-A), with a root mean square (rms) surface roughness in the range of $50 \mathrm{~nm}$ to $90 \mathrm{~nm}$ and lateral feature sizes varying between $300 \mathrm{~nm}$ and $500 \mathrm{~nm}$. For microcrystalline cells, photons with wavelength varying from $800 \mathrm{~nm}$ to $1100 \mathrm{~nm}$ can be absorbed, as the material exhibits a lower band-gap than amorphous silicon, but the absorption is weak and therefore light scattering in this spectral range is mandatory, furthermore coupled to effective reflection at the back contact of the device. Multiple scattering at the TCO/silicon 
interfaces can result in, at least, a five-fold increase in the optical path within the intrinsic layer [19], and allow for the design of high efficiency $\mu \mathrm{C}$-Si:H solar cells while keeping industrially reasonable material thicknesses (below $2 \mu \mathrm{m}$ ). The LPCVD ZnO texture optimized at the IMT-EPFL for light trapping in $\mu \mathrm{C}-\mathrm{Si}: \mathrm{H}$ based solar cells is shown in Figure 2 right (type-C), with surface roughness of about $180 \mathrm{~nm} \mathrm{rms}$ and lateral feature sizes varying between $1000 \mathrm{~nm}$ and $1400 \mathrm{~nm}$. The type-A $\mathrm{ZnO}$ is strongly doped and $1.8 \mu \mathrm{m}$ thick, while the type- $\mathrm{ZnO}$ is lightly doped (to keep low free carrier absorption) and $4.8 \mu \mathrm{m}$ thick, so that the sheet resistance of both substrates is of about $10 \Omega / \mathrm{sq}$.

The optical characteristics of the two $\mathrm{ZnO}$ types are shown in Figure 3; the haze being defined as the ratio of diffuse to total transmission $H=T_{D} / T_{T}$, while the angle resolved scattering (ARS) is the intensity scattered into angles between 0 and $90^{\circ}$ for a fixed wavelength (here of $543 \mathrm{~nm}$ ). For randomly rough surfaces with a correlation length much smaller than the wavelength, scalar scattering theory predicts the following relation between haze and wavelength [20, 21].

$$
H=1-\exp \left\{-\left(\frac{2 \pi \sigma}{\lambda}\left|n_{1} \cos \theta_{1}-n_{2} \cos \theta_{2}\right|\right)^{\beta}\right\}
$$

The angles $\theta_{1}$ and $\theta_{2}$ represent the directions of the incident and of the scattered beams, respectively; $n_{1}$ and $n_{2}$ are the corresponding refractive indices. The exponent $\beta$ should be equal to 2 , but different values have been reported experimentally [21,22]. The haze data are shown in Figure 3; and we find $\beta$ values of 2.8 and 2 for the type-A and the type-C substrate, respectively [23]. The ARS data in the right panel are plotted after weighting with the sinus of the scattered angle which provides the shape of the probability density function associated to the angular distribution. The type-A substrate shows a maximum at $40^{\circ}$ which is very close to the behavior of an ideal Lambertian diffuser (maximum at $45^{\circ}$ ), indicating that it scatters effectively into high angles. The type-C substrate scatters into a narrower angular distribution, the most probable scattering angle being only $20^{\circ}$. Assuming rotational symmetry with respect to surface normal (ARS not dependent on the polar angle $\varphi$ ), the integrated areas under the curves are proportional to the diffuse part of the transmittance $T_{D}$. Their variation reflects the different haze values for the wavelength of the ARS measurement, in this case at $543 \mathrm{~nm}$.
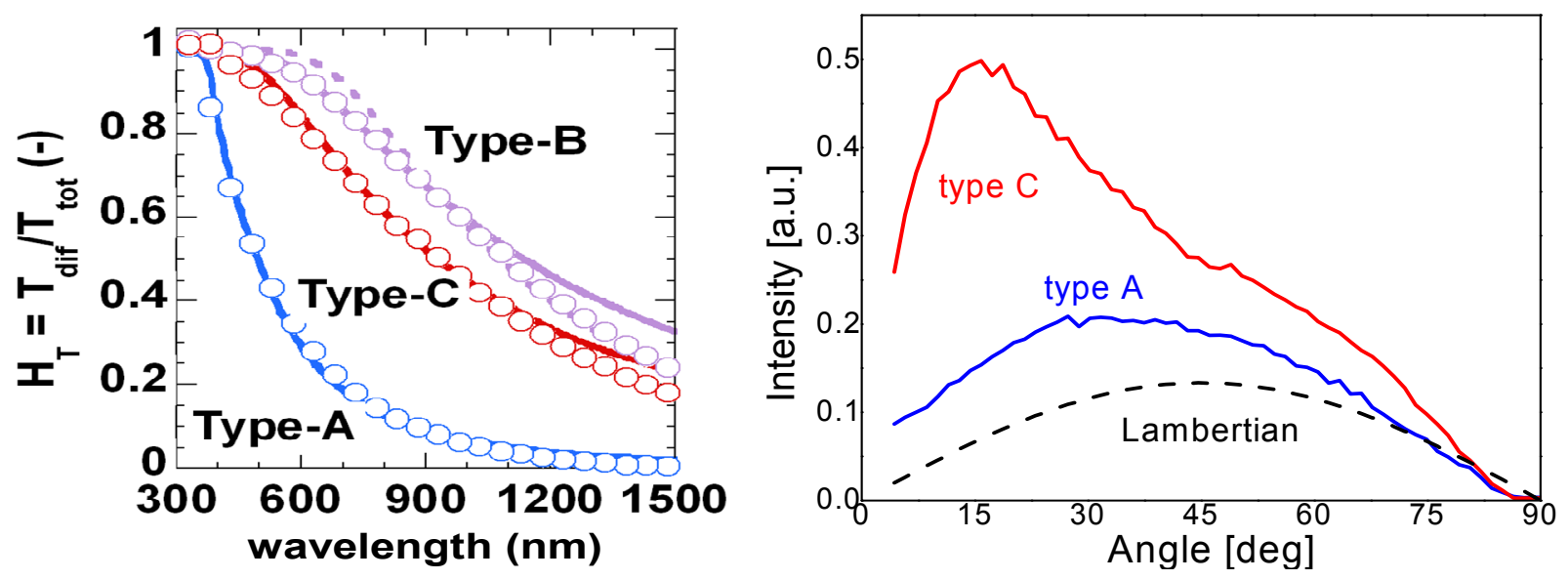

Fig. 3. Left: Spectral haze of the type-A and type-C ZnO. Right: sinus weighted ARS; the dotted line illustrates ideal Lambertian scattering.

\subsection{Impact of the substrate geometry onto thin film silicon solar cells growth and electrical performance}

The type-C ZnO shows a high haze value, but direct growth of $\mu \mathrm{C}-\mathrm{Si}$ :H onto such rough surface leads to low electrical performance of the developed solar cells [9]. The growth mechanisms of microcrystalline silicon was shown to result in defective material above steep, V-shaped depressions [24, 25]. These micro-structural defects correspond to zones of porous material growing as cracks, typically at the bottom of the surface valleys, where pinches are present, and we have 
shown that these cracks can be considered in the device equivalent circuit as low quality factor parallel diodes [24] mostly responsible for the observed decrease in electrical performances (low open-circuit voltage, low fill factor). These zones of porous material are consequences of shadowing effects and collision of growth front, linked to low ad-atom diffusion, and an example of such crack growth is shown in the transmission Electron micrograph (TEM) of Figure 4 left for a p-i-n single-junction $\mu \mathrm{C}$-Si:H solar cell deposited on as-grown type-C $\mathrm{ZnO}$. Here, the crack, followed by a dashed line and appearing as white contrast line, propagates through the whole active part of the i-layer. It is worth stressing that these "cracks" have been observed by different other groups, for different other TCOs or substrates, in $\mu \mathrm{C}-\mathrm{Si}: \mathrm{H}$ and in a$\mathrm{Si}: \mathrm{H}$ solar cells [26,27] or particle detectors [28], and that they are determined by the substrate morphology and geometry. Reduction of this low quality material density is therefore crucial for the development of high efficiency thin film silicon solar cells.

A post-processing plasma treatment of the TCO surface was developed at the IMT-EPFL [9] and was shown to change the initial V-shaped morphology of the substrate features to U-shaped morphology. Depending on the duration of the treatment, the roughness is reduced down to $120 \mathrm{~nm} \mathrm{rms}$, and a type-C $\mathrm{ZnO}$ surface after the plasma treatment is shown in Figure 2. This surface treatment permits to suppress or limit the smaller pyramids of the $\mathrm{ZnO}$ surface and allows for smoother surface morphology, drastically reducing the density of cracks in the developed cells. This is first illustrated in Figure 4 with a TEM image of a p-i-n single-junction $\mu \mathrm{C}$-Si:H solar cell deposited on a type-C $\mathrm{ZnO}$ treated 40 minutes, where we can see a smaller crack which propagates only through part of the i-layer. Finally, a TEM image of a p-i-n single-junction $\mu \mathrm{C}-\mathrm{Si}: \mathrm{H}$ solar cell deposited on a type-C $\mathrm{ZnO}$ treated 80 minutes demonstrates no visible cracks in the active part of the device. The density of cracks was evaluated by observations of different TEM or SEM images [24], on single-junction $\mu \mathrm{C}$-Si:H solar cells previously characterized, and results directly demonstrate the correlation between the cracks density and the cell electrical performance, as shown in Figure 5.

\section{Type-C ZnO}

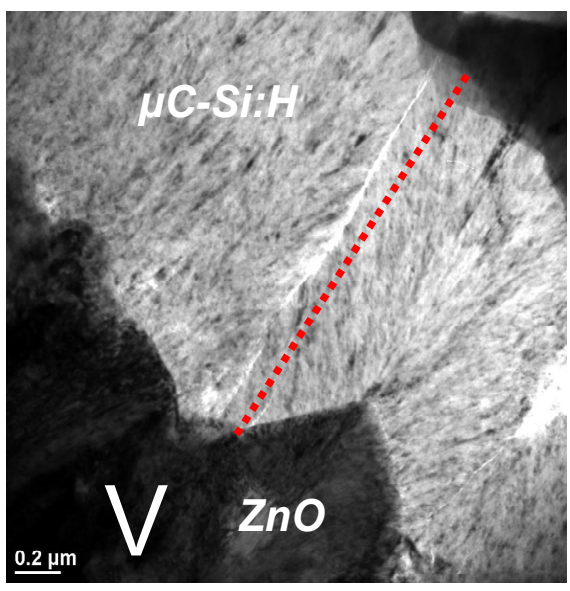

Type-C ZnO treated 40'

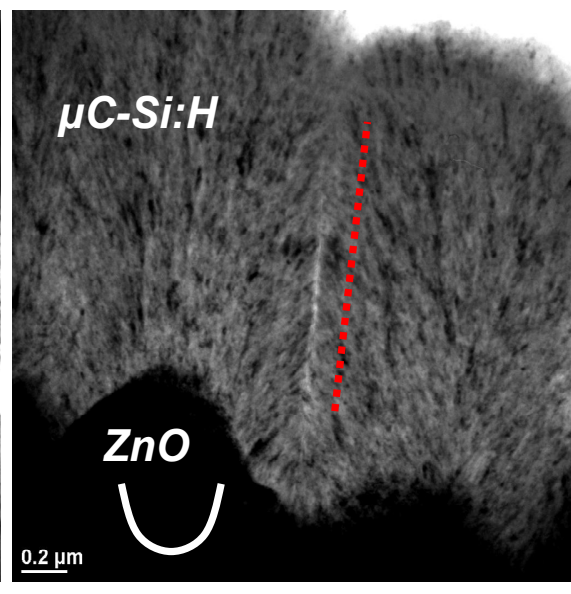

Type-C ZnO treated 80'

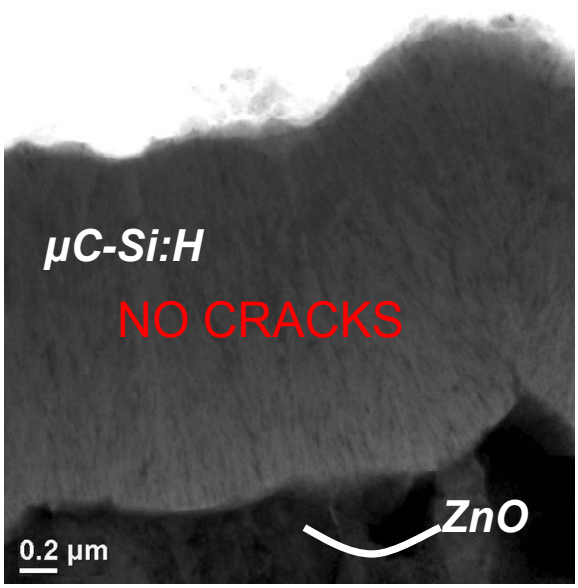

Fig. 4. Bright field TEM cross-section micrographs of $\mu \mathrm{C}$-Si:H p-i.n cells on $\mathrm{V}$-shaped type $\mathrm{C} \mathrm{ZnO}$ as grown (left) and on U-shaped treated type $\mathrm{C} \mathrm{ZnO}$. Surface treatment allows for an increse of the radii of curvature of the valleys, as illustrated on the bottom of each picture (middle: 40 minutes treatment, right, 80 minutes treatment), as presented in [24].

In consequence, while large sized structures with high haze and with high angle angular scattering are preferred to optimize light confinement in thin film silicon solar cells, specific care has to be taken so as to allow for dense $\mu \mathrm{C}-\mathrm{Si}: \mathrm{H}$ growth, i.e. without porous material growing as cracks, to ensure good electrical performance of the developed cells. According to our experimental observations, the large features TCOs to be use have to exhibit smoothed substrate's valley with sufficient radii of curvature to lead to the optimum thin film solar cell. 

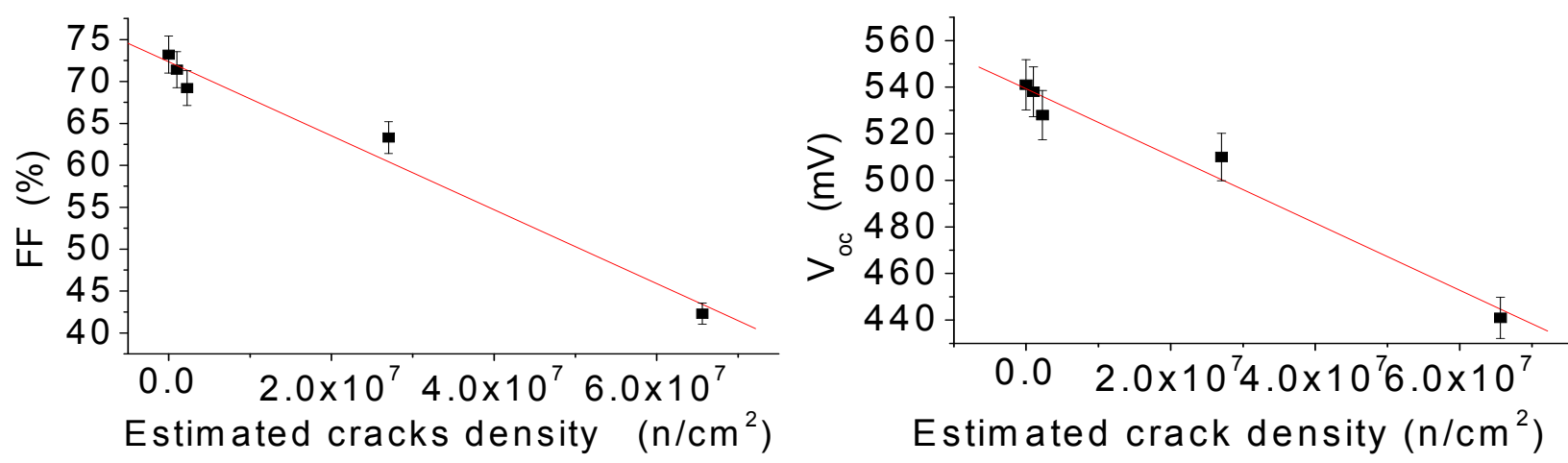

Fig. 5. Decrease in the electrical performance parameters VOC and FF of p-i-n single junction single-junction $\mu \mathrm{C}$-Si:H solar cells as a function of the crack density estimated from TEM micrographs. Lines are linear fit [24].

\section{HIGH EFFICIENCY P-I-N MICROMORPH CELLS}

In micromorph tandem cells, both a-Si:H and $\mu \mathrm{C}-\mathrm{Si}: \mathrm{H}$ silicon absorbers are combined in the same device, so that it becomes challenging to devise light scattering strategies that can effectively serve the different spectral ranges of the two individual cells. The fundamental step to achieve effective light management in such solar cells is the introduction of an intermediate reflector layer between the two cells, because high light trapping in the amorphous top cell is quite impossible without reflection of light directly at its back. This top cell improved light management is of paramount importance to allow the design of a thin (below $300 \mathrm{~nm}$ to $350 \mathrm{~nm}$ ) a-Si:H junction, so as to limit the electrical performance degradation under light exposure which originates from metastable increased defect density in the material (Staebler-Wronski effect). Higher currents can therefore be expected for thinner a-Si:H top cell with the use of appropriate intermediate reflector. The micromorph tandem structure utilizing such reflector is shown in Figure 1 and latest developments of intermediate reflectors at the IMT-EPFL and their integration into cells are discussed in sections 3.1 and 3.2. A TCO structure which could combine small and large features of the type-A and type-C TCO presented in section 2 was also developed. Tentative ideas were that the fine features could provide light diffusion in the top cell while the flattening effect of growing the amorphous layer should not affect too seriously large features, which could then diffuse longer wavelengths for light trapping in the bottom cell. We could successfully fabricate $\mathrm{ZnO}$ surfaces showing such double size textures [29], but so far their application into tandem solar cells did not show a clear improvement and single structure large grain TCO (treated type-C) still leads to the best stable efficiencies.

\subsection{In-situ PECVD deposited Intermediate reflector}

The intermediate reflector to be integrated in a micromorph tandem cell needs to have a low refractive index so as to achieve high index contrast with silicon. This leads to a higher reflection of incoming photons, most of all due to a low critical angle at the first interface silicon-intermediate reflector, allowing for a larger fraction of photons to be totally reflected back into the a-Si:H top cell to increase the generated current density. A sufficient transverse conductivity of the layer is also required, together with low absorption and reflection of near-infrared photons to minimize current density losses for the bottom microcrystalline junction. The deposition process specificities and implications have finally also to be taken into account for the industrialization of such intermediate reflector. The first implementations of intermediate reflectors (IR) in multi-junction solar cells were done by using zinc oxide based IR (ZIR) [30], which has a typical refractive index close to 2 at $600 \mathrm{~nm}$ (while it is about 4 for silicon). Further researches on alternative solutions led to the demonstration of the high potential of using PE-CVD in-situ deposited silicon oxide based intermediate reflectors (SOIR) [31], which have become now established in production of micromorph tandem modules [32].

The absorption and reflection of photons with wavelengths varying from $350 \mathrm{~nm}$ to $1200 \mathrm{~nm}$ were measured on both zinc oxide and silicon oxide based intermediate reflectors. The refractive index was extracted from these measurements 
for both IR layers and performances are compared in Figure 6, showing that the SOIR should permit to attain higher reflection thanks to a lower refractive index than with ZIR, as $\mathrm{n} \sim 1.7$ to 1.9 at $600 \mathrm{~nm}$ for SOIR and $\mathrm{n} \sim 2$ for ZIR at $600 \mathrm{~nm}$. The deposited SOIR layers also exhibit lower absorption coefficient in the near-infrared than the ZIR deposited layers. Moreover, higher shunting probabilities were observed when incorporating ZIR layers, while SOIR carefully designed with sufficient transverse conductivity and higher lateral conductivity can lead to improved low illumination electrical performance of the solar cells. Finally, the ZIR is deposited in a system different to the PE-CVD reactors used for the amorphous and microcrystalline layers, therefore not easing the solar cell deposition sequence. The Silicon Oxide layers, even though grown at a reduced typical growth rate $(\sim 0.1 \mathrm{~nm} / \mathrm{s}$ versus about $2 \mathrm{~nm} / \mathrm{s}$ for $\mathrm{ZnO})$, have the high advantage to be deposited in PE-CVD reactors, typically from a mixture of $\mathrm{CO}_{2}$ (or alternatively of $\mathrm{N}_{2} \mathrm{O}$ ), $\mathrm{SiH}_{4}, \mathrm{H}_{2}$ and $\mathrm{PH}_{3}$ gases, i.e. same process as for the absorbers. The developed SOIR layers exhibit a dual-phase nature, with silicon nanocrystals embedded in an amorphous silicon oxide matrix. Variations of the deposition processes permit to develop layers with varying refractive index n (from 1.55 to 3 at $600 \mathrm{~nm}$ wavelength) and conductivity (from about $10^{-10}$ to $10^{-2}$ $\mathrm{S} / \mathrm{cm}$ ), depending on the size and density of the silicon nanocrystals phases [31]. The SOIR deposition regimes were varied in order to achieve lower index of refraction with sufficient transverse conductivity. Low-plane conductivity is required for the IR layers but they need to have sufficient transverse conductivity to not increase too much the series resistance of the solar cell, to not impact efficiency. Variations of the hydrogen dilution of the gas mixture and of the $\mathrm{CO}_{2}$ content were tested. An increase of $\mathrm{CO}_{2}$ content clearly leads to a decrease of index of refraction, as shown in Figure 6, thanks to an improved incorporation of oxygen in the layers. High hydrogen dilution permits to lower the index of refraction (Figure 6) by reducing the presence of silicon phase in the developed layers, but it leads also to lower conductivity of the layers.
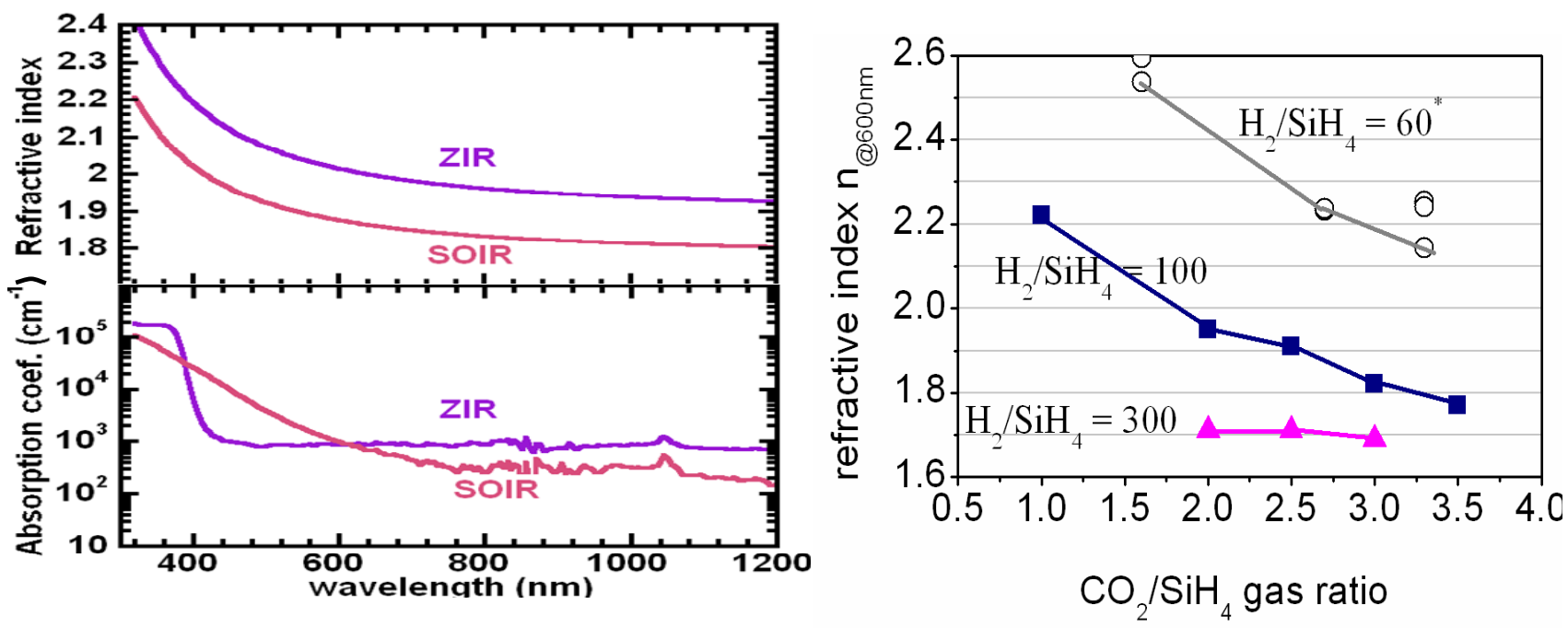

Fig. 6. Left: Absorption coefficient and refractive index measured on both zinc oxide based intermediate reflectors and on silicon oxide based intermediate reflectors. Right: Refractive indices measured on silicon oxide based intermediate reflectors in different deposition regimes, i.e. for varying $\mathrm{H}_{2} / \mathrm{SiH}_{4}$ and $\mathrm{CO}_{2} / \mathrm{SiH}_{4}$ gas flow ratio [31].

The two intermediate reflector solutions were integrated in micromorph cells developed both on type-A and on type-C LP-CVD $\mathrm{ZnO}$ front contact. The depositions were done for varying thicknesses of the intermediate reflector. Both solutions demonstrate an increase of current density in the a-Si:H top cell and the results obtained on cells with $180 \mathrm{~nm}$ thick a-Si:H top cells and $1.8 \mu \mathrm{m}$ thick $\mu \mathrm{c}-\mathrm{Si}: \mathrm{H}$ bottom cells are presented in Figure 7. The ZIR and SOIR permit a similar maximum increase of current density in the developed cells of about $2.4 \mathrm{~mA} / \mathrm{cm}^{2}$ for $200 \mathrm{~nm}$ to $300 \mathrm{~nm}$ thick layers and for depositions carried out on a type-A TCO. The current gain saturates for increasing reflector thicknesses so that a $200 \mathrm{~nm}$ thick reflector seems to be optimum. The current gain in the top cell attained thanks to the intermediate reflector is lower for the substrates with larger feature sizes, as shown in Figure 7 with the lower gain for type-C front TCO, observed with the 2 different IR solutions. This originates from the differences in the angular scattering of the incoming photons at the TCO substrate. As shown in Figure 3, the type A TCO leads to a rather lambertian distribution of the emitted light, therefore giving rise to a larger proportion of incoming photons scattered at large angles for photons with wavelength of about $550 \mathrm{~nm}$. These higher diffusion angles for the type-A TCO than for the type-C TCO for 
wavelength in the range of $550 \mathrm{~nm}$ to $750 \mathrm{~nm}$ permits a higher proportion of photons arriving at the silicon-IR interface at angles higher than the critical angle, leading to improved reflection and to higher short circuit current densities in the a-Si:H top cell.

SOIR

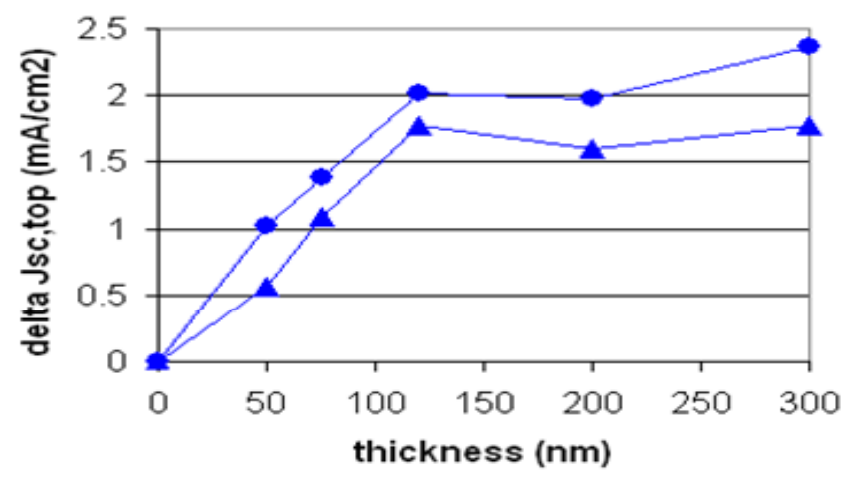

ZIR

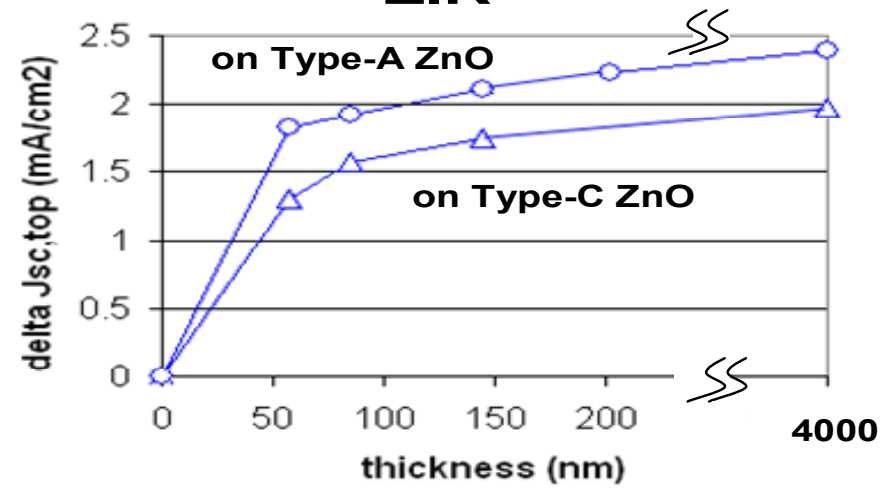

Fig. 7. Comparison of the measured increase in short circuit current density in $180 \mathrm{~nm}$ thick a-Si:H top cells incorporated in micromorph cells with $1.8 \mu \mathrm{m}$ thick $\mu \mathrm{C}$-Si:H cells, for varying thicknesses of both silicon oxide based intermediate reflectors (left) and zinc oxide based intermediate reflectors (right). The micromorph cells were deposited both on typeA and on type-C TCOs, and corresponding measurements depending on substrate type are also presented [31].

\subsection{Micromorph p-i-n solar cells with in-situ silicon oxide intermediate reflector}

The combinations of the developed high haze transparent conductive oxides and low refractive index intermediate reflectors have allowed to improve light management in the micromorph solar cells. The best results in small-area PECVD reactors at the IMT-EPFL were obtained so far using a type-C LPCVD ZnO (permitting higher diffusion of long wavelength photons and increased current in the $\mu \mathrm{C}$-Si:H bottom cell) and $150 \mathrm{~nm}$ thick SOIR layers (with a refractive index estimated to about 1.7 at $600 \mathrm{~nm}$ ). The electrical performance of a micromorph solar cell developed at the IMTEPFL combining a top cell thickness of $300 \mathrm{~nm}$, a bottom cell thickness of $3 \mu \mathrm{m}$, and a SiOx intermediate reflector layer of $150 \mathrm{~nm}$ thickness, is shown in Figure 8. In this configuration, and without anti-reflection coating, we obtain an initial efficiency of $12.6 \%$ which shows a relative degradation of $12 \%$ after $1000 \mathrm{~h}$ of light soaking, reaching a stabilized efficiency of at $11.1 \%$. The area of this cell is $1.2 \mathrm{~cm}^{2}$.
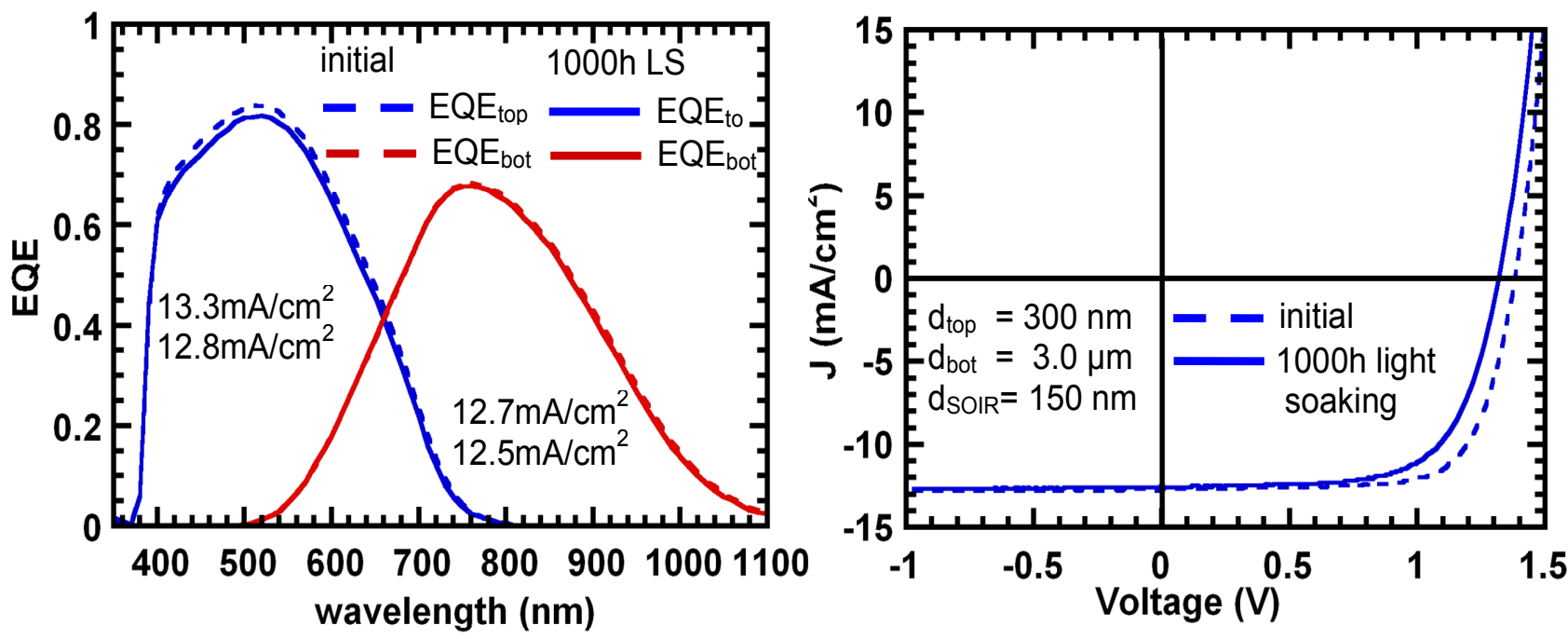

Fig. 8. External Quantum Efficiency (EQE) and current voltage characteristics of a micromorph tandem solar cell deposited on the type $\mathrm{C}$ substrate with SOIR, in its initial and stabilized state (cell size $1.2 \mathrm{~cm}^{2}$, no anti-reflection coating) [29]. 
Other micromorph solar cells were further developed so as to optimize the cell short circuit current density. The results obtained with the combination of an a-Si:H cell thickness of $340 \mathrm{~nm}$, a $\mu \mathrm{C}-\mathrm{Si}: \mathrm{H}$ bottom cell thickness of $3.5 \mu \mathrm{m}$ and a $\mathrm{SiOx}$ intermediate reflector layer of $150 \mathrm{~nm}$ thickness, are shown in Figure 9. In this configuration, and with antireflection coating applied to the front glass, we obtain an initial efficiency of $13.3 \%$, thanks to a high total generated current of $27.7 \mathrm{~mA} / \mathrm{cm}^{2}$ in the micromorph solar cell, with a current matched at about $13.8 \mathrm{~mA} / \mathrm{cm}^{2}$. The area of this cell is here also of $1.2 \mathrm{~cm}^{2}$.
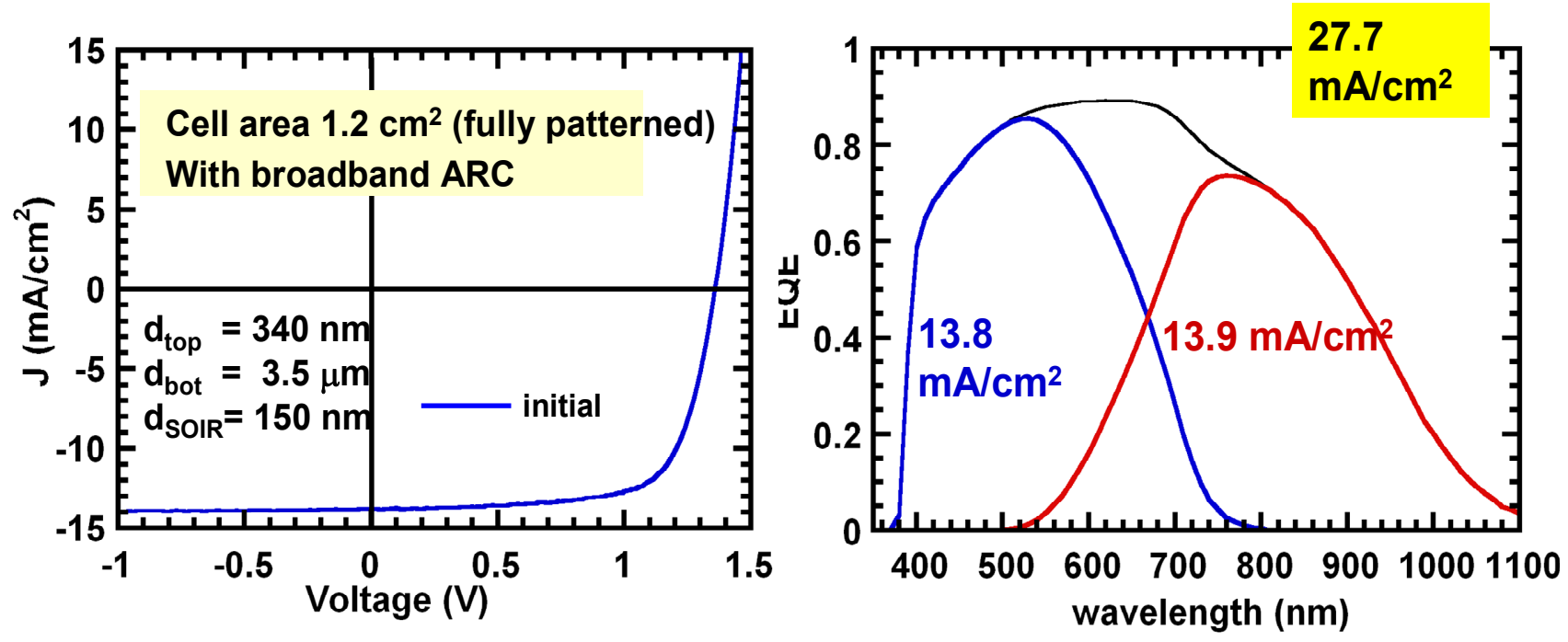

Fig. 9. External Quantum Efficiency (EQE) and current voltage characteristics of a micromorph tandem solar cell deposited in the small-area PE-CVD system, on the type C substrate, with SOIR, optimized to reach high short circuit current density in its initial state (cell size $1.2 \mathrm{~cm}^{2}$, no anti-reflection coating) [29].

Similar concepts for improved light management in micromorph cells were then also applied in large-area industrial like PECVD reactor (KAI R\&D system). This permitted an improvement of the developed micromorph cells initial efficiency up to about $12.3 \%$. The initial EQE and current voltage characteristics of this tandem solar cell, incorporating a $250 \mathrm{~nm}$ thick a-Si:H top cell, a $2.7 \mu \mathrm{m}$ thick $\mu \mathrm{C}-\mathrm{Si}: \mathrm{H}$ bottom cell (deposited at $3.5 \AA / \mathrm{s}$ ) and a $130 \mathrm{~nm}$ thick SOIR, on the type C substrate, are shown in (cell size $1.2 \mathrm{~cm}^{2}$, with anti-reflection coating). These results show the possibility of integrating industrially the developed device features to get higher light confinement in thin film silicon solar cells.
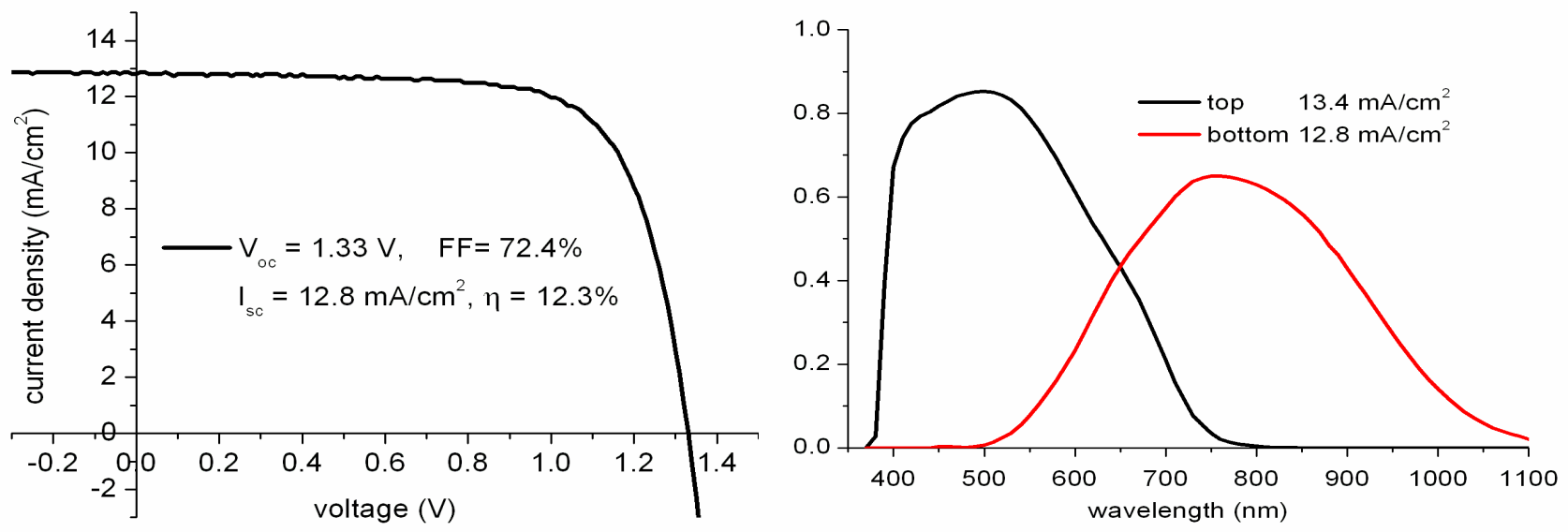

Fig. 10. External Quantum Efficiency (EQE) and current voltage characteristics of a micromorph tandem solar cell deposited in the large-area KAI PE-CVD system, on the type C substrate, with SOIR (cell size $1.2 \mathrm{~cm}^{2}$, no antireflection coating). 


\section{ADVANCED LIGHT TRAPPING IN N-I-P THIN FILM SILICON SOLAR CELLS}

In order to reach high efficiency micromorph solar cells in the n-i-p configuration, advanced light scattering strategies are also needed, such as implementing different length scales for light trapping, either in the same interface by overcoating a large structure with smaller features, or by varying the texture between the individual interfaces. Similar concepts as developed for the front TCO in p-i-n thin film silicon solar cells can be followed in substrate (n-i-p) devices but here for achieving textured metallic back contacts. Light scattering is in this case therefore achieved at the reflection at the back contact and not at the transmission at the front contact as realized in the p-i-n configuration.

The n-i-p cells presented here are grown on a flexible polyethylene substrate and the surface morphology of the substrate is textured with a periodic sinusoidal structure which is embossed into the surface by a roll-to-roll process [33]. The substrate is then covered in a conformal way by sputtering of a bilayer of silver and zinc oxide with typical thicknesses of $80 \mathrm{~nm}$ and $60 \mathrm{~nm}$, respectively. The silicon layers are then deposited at $180^{\circ} \mathrm{C}$ by very high frequency PE-CVD. The front contact consists of a $1.8 \mu \mathrm{m}$ to $3.8 \mu \mathrm{m}$ thick $\mathrm{ZnO}$ layers deposited by LPCVD (naturally textured growth), similar to the $\mathrm{ZnO}$ processes developed for the $\mathrm{p}$-i-n case (respectively type-A and type- $\mathrm{C} \mathrm{ZnO}$ ).

In order to realistically estimate the total current attainable in a micromorph tandem device while using such textured substrates, the dependence of the photocurrent of the $\mu \mathrm{C}-\mathrm{Si}: \mathrm{H}$ cell thickness was first studied. The EQEs of a series of microcrystalline cells grown onto the 2D grating substrate are presented in Figure 11, with i-layer thickness varying from $1.1 \mu \mathrm{m}$ to $3 \mu \mathrm{m}$. A high increase of photocurrent can be observed from $23 \mathrm{~mA} / \mathrm{cm}^{2}$ to $24.5 \mathrm{~mA} / \mathrm{cm}^{2}$, respectively for 1.1 $\mu \mathrm{m}$ to $2 \mu \mathrm{m}$ thick i-layers. For thicker i-layers, the photocurrent rise tends to saturate at about $25.1 \mathrm{~mA} / \mathrm{cm}^{2}$. In this study, further increase of thickness leads to degradation of the electric performance of the solar cell, so that the saturation of the generated current rather reflects a problem of carriers collection than the actual limit of light trapping. Improved processing of the microcrystalline i-layer could certainly allow for higher current densities with our substrate texture.
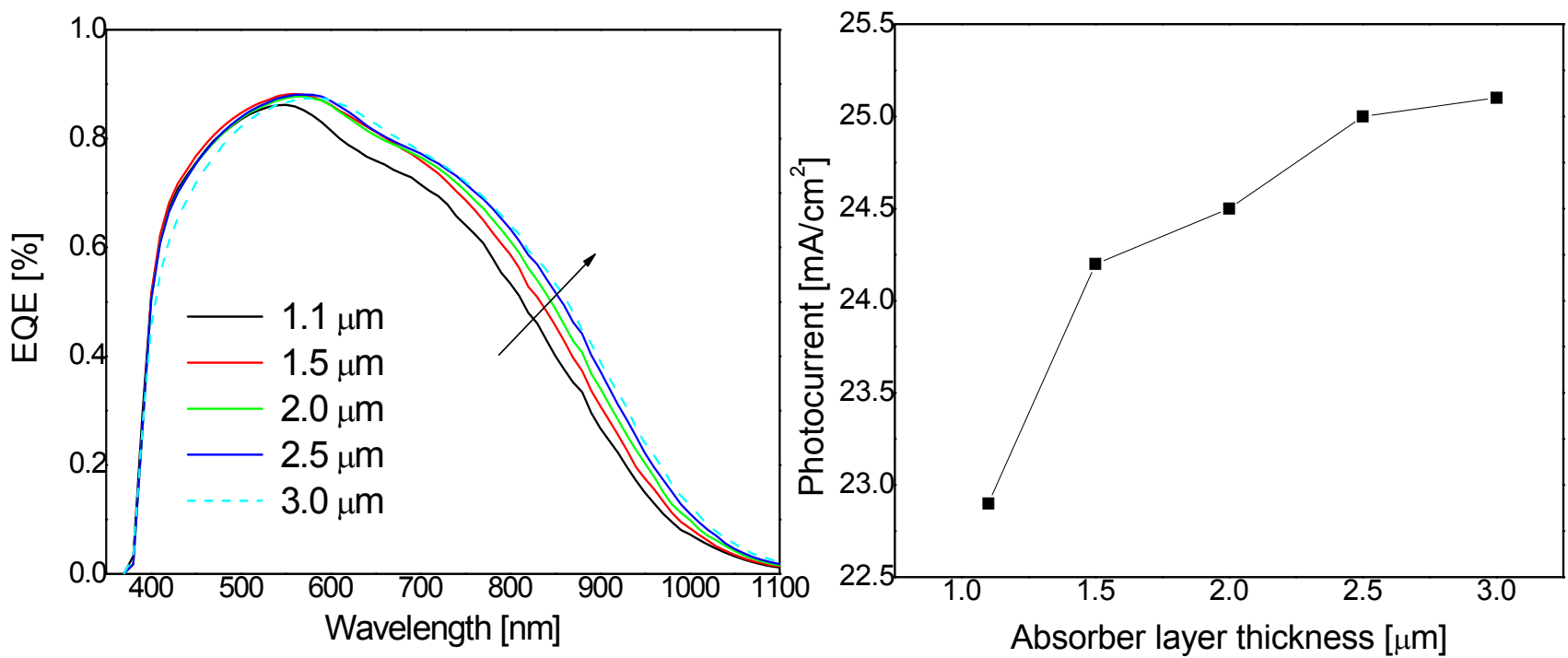

Fig. 11. External Quantum Efficiency (EQE) of microcrystalline solar cells on the periodic texture (left) and the dependence of photocurrent on the i-layer thickness (right) [34].

A possible total current density of $25 \mathrm{~mA} / \mathrm{cm}^{2}$ can therefore be reasonably expected to be achieved for the time being with the developed substrate texture. Such total current density would allow for a maximum matched current in a micromorph tandem solar cell of about $12.5 \mathrm{~mA} / \mathrm{cm}^{2}$. However, such current density becomes challenging to obtain in the amorphous silicon top cell. If we consider the simpler case in which the amorphous top cell is stacked onto the microcrystalline bottom cell without any intermediate layer, we can assume only single pass of photons through the 
amorphous absorber layer. After passing through the top cell, the remaining light active for amorphous silicon (below $850 \mathrm{~nm}$ ) will likely interact in the bottom cell and not come back to the top cell, so that the amorphous silicon cell in such tandem configuration does not benefit from the back reflector. The thickness series of top n-i-p amorphous cells presented in Figure 12 show that an i-layer thickness of more than $600 \mathrm{~nm}$ would be required to obtain a photocurrent of more than $12 \mathrm{~mA} / \mathrm{cm}^{2}$. Clearly, such a thickness is not desirable in terms of light induced degradation and a maximum current of about $10.5 \mathrm{~mA} / \mathrm{cm}^{2}$ was measured after 1000 hours of light soaking at $50 \mathrm{~mW} / \mathrm{cm} 2$.
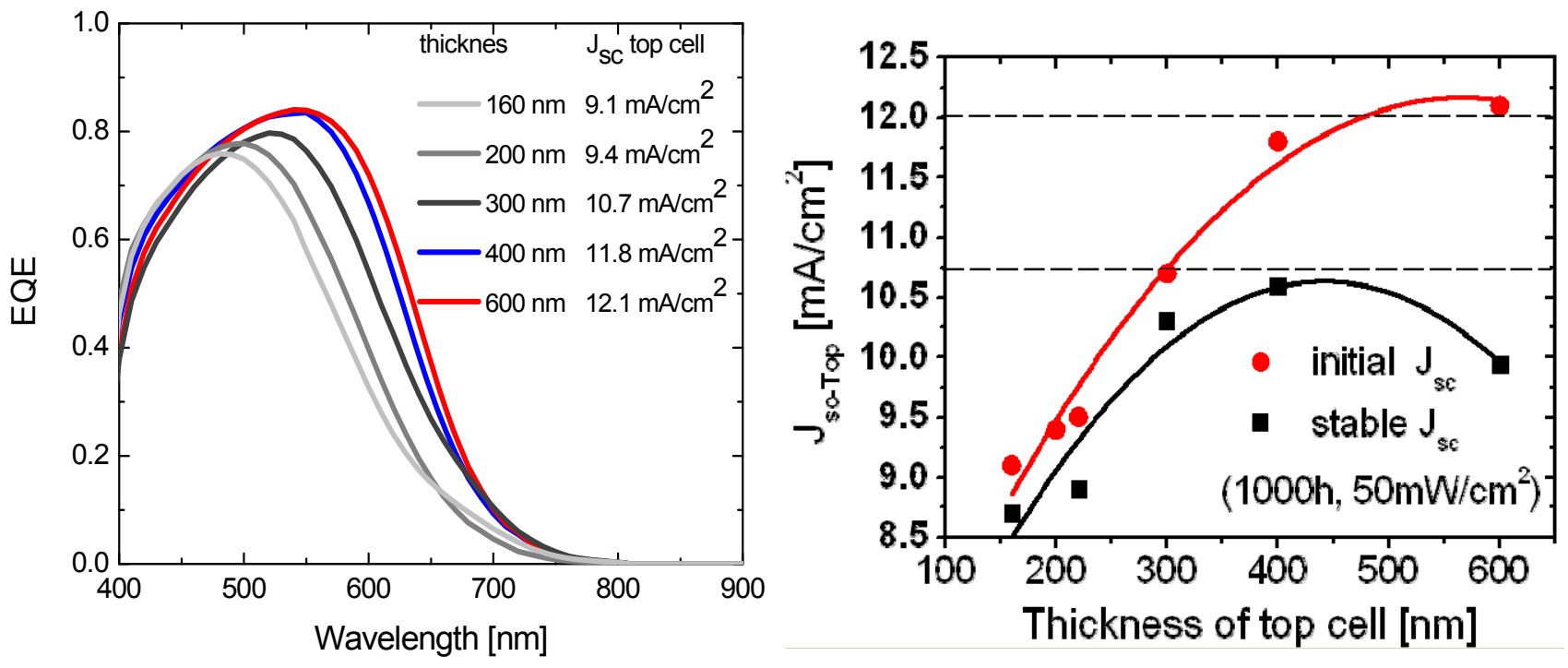

Fig. 12. EQEs of the top cell in n-i-p/n-i-p tandem cells on the flexible substrate. The left panel illustrates the variation of i-layer thickness, the right panel illustrates the importance of the a-Si:H layer thickness onto the degraded state [34].

By introducing a layer of lower refractive index between the two cells, an interference condition can be established where poorly absorbed light in the range between 600 and $750 \mathrm{~nm}$ is selectively reflected back into the amorphous silicon absorber layer, as already developed in the p-i-n configuration micromorph solar cells. Results obtained by using similar silicon oxide intermediate reflector as presented in section 3.2, are shown in Figure 13.

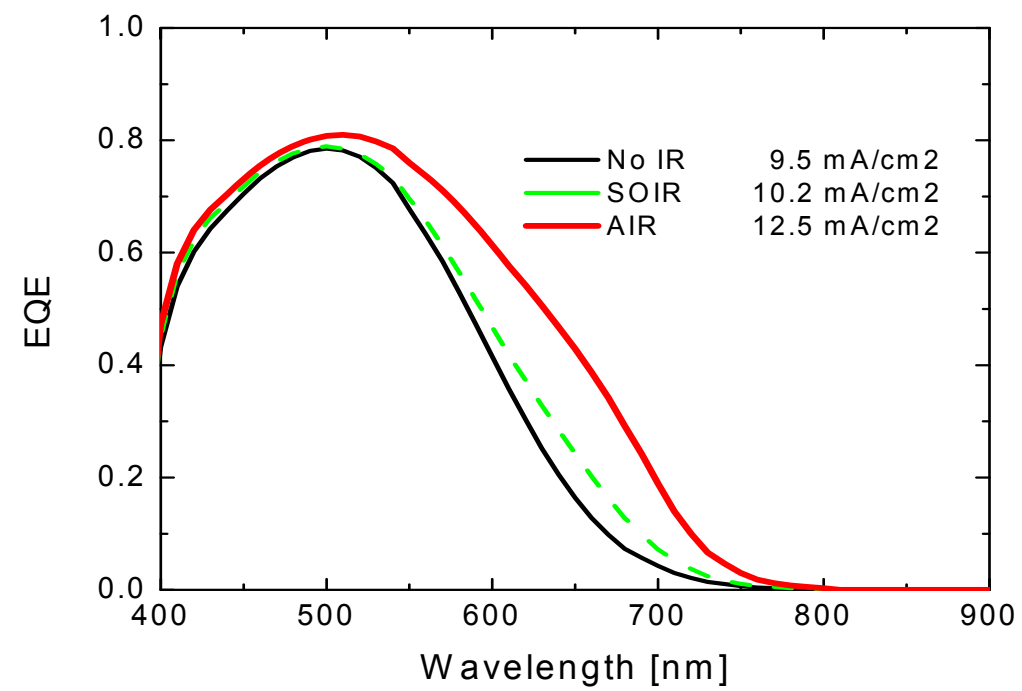

Fig. 13. EQEs of the top cell in n-i-p/n-i-p tandem cells on the flexible substrate, illustrating the importance of a textured intermediate reflector layer (i-layer thickness: $200 \mathrm{~nm}$ ) [34]. 
The $100 \mathrm{~nm}$ thick, nominally flat SOIR, permits to first improve the current in a $200 \mathrm{~nm}$ thick top cell from $9.5 \mathrm{~mA} / \mathrm{cm}^{2}$ to $10.2 \mathrm{~mA} / \mathrm{cm}^{2}$. However, we are still far from the targeted photocurrent of $12.5 \mathrm{~mA} / \mathrm{cm}^{2}$, and far from the current increase achieved in the $p-i-n$ configuration. First, the periodic substrate in the $n-i-p$ configuration exhibits a period of $1200 \mathrm{~nm}$ which is well matched to the requirements of the microcrystalline silicon bottom cells, but not necessarily to amorphous silicon cells. Still, in $270 \mathrm{~nm}$ thick single junction amorphous cells deposited directly on this substrate, photocurrents between $12.8 \mathrm{~mA} / \mathrm{cm}^{2}$ and $14.4 \mathrm{~mA} / \mathrm{cm}^{2}$ [33] could be achieved, with a certainly higher reflection at the $\mathrm{ZnO} / \mathrm{Ag}$ back contact used as back reflector than the reflection which can be attained with the SOIR in the tandem cell. Moreover, the texture of the back contact is changed by the growth of the microcrystalline bottom cell, as shown in Figure 14 by a cross section image of a tandem cell on the periodic reflector incorporating an intermediate reflector. We observe that the amplitude of the substrate texture is reduced towards the top of the microcrystalline layer, and the sinusoidal shape is changed towards a mostly flat interface with small depressions located along the minima of the initial structure. Thus, the reflection at the SOIR can yield a second pass of light through the top cell, but we expect only little scattering of light at the flattened interface, while the lower interface morphology features does lead to lower angle of photons impinging onto the silicon to intermediate reflector interface, therefore strongly reducing the number of photons exhibiting total reflection. Correspondingly, the top cell as developed with the SOIR layer compares well to flat reference cells on a good reflector (e.g. $11 \mathrm{~mA} / \mathrm{cm}^{2}$ for a $270 \mathrm{~nm}$ thick cell $[34,35]$ ).

In order to achieve improved light scattering in the top cell, an asymmetric intermediate reflector (AIR) made of $\mathrm{ZnO}$ and grown by LPCVD [34] was introduced. Inherent to the growth process, LPCVD ZnO develops a textured surface regardless whether the substrate is flat or mildly textured, and it is well documented that this surface texture is well adapted to amorphous solar cells [36]. The cross section image of a micromorph solar cell integrating such $\mathrm{ZnO}$ intermediate reflector displayed in Figure 14, shows that the 1.6 $\mu \mathrm{m}$ thick LPCVD-ZnO layer completely fills the small depressions in the surface of the microcrystalline layer, and develops its own typical pyramidal texture independently of the original periodicity.

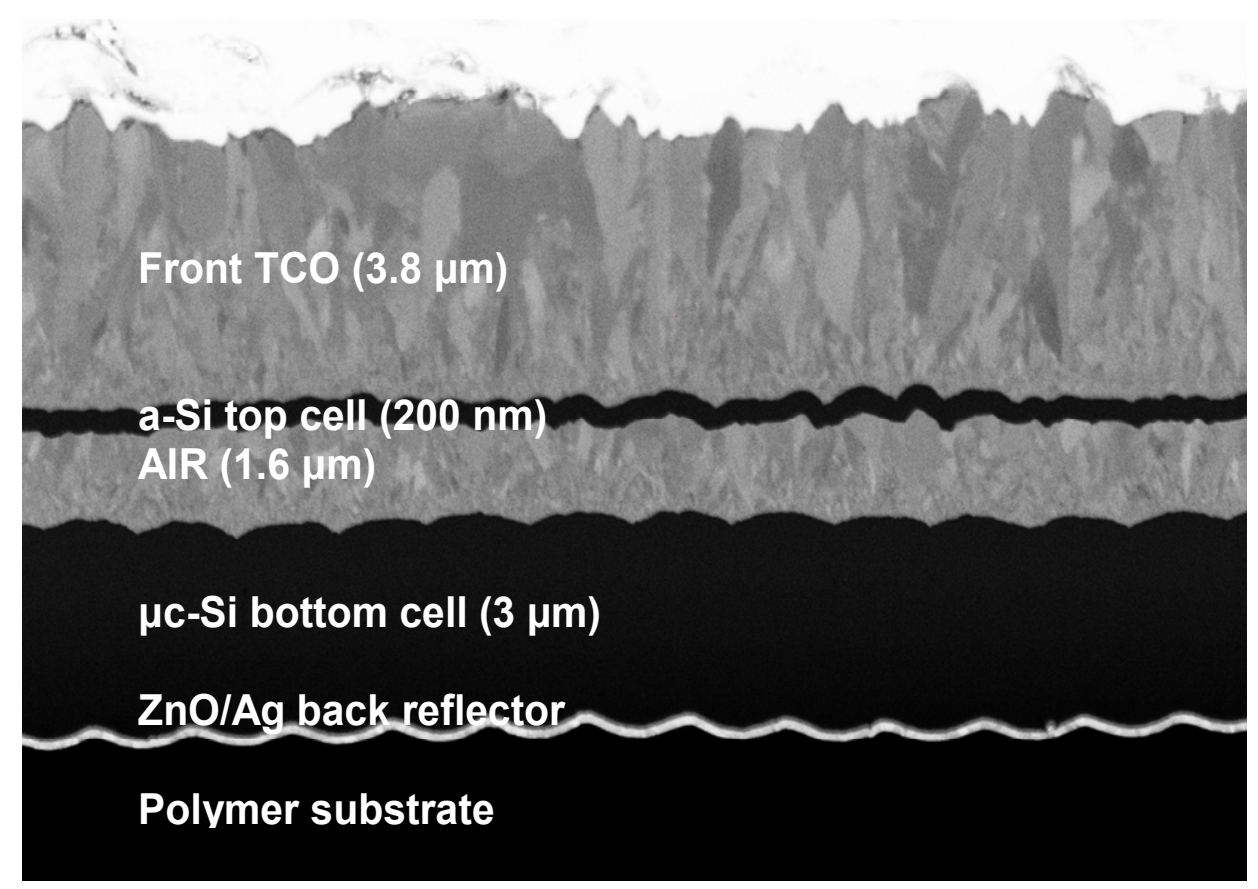

Fig. 14. Cross section image through a micromorph tandem cell with LPCVD-ZnO AIR on the periodically textured polymer substrate [34]. 
The use of this assymetric intermediate reflector allows for much higher roughness at the interface between the top cell and the reflector, therefore allowing for higher reflection and for higher diffusion and scattering of the reflected light. This directly translate into a massive improvement of the top cell current density, as we could achieve the goal of $12.5 \mathrm{~mA} / \mathrm{cm}^{2}$ in a $200 \mathrm{~nm}$ thick amorphous cell by using such intermediate reflector. The best micromorph n-i-p cell was obtained thanks to the AIR development and showed an initial efficiency of $11.2 \%$, for a stabilized efficiency of $9.8 \%$ after $1000 \mathrm{~h}$ of light soaking, and its performance are displayed in Figure 15.
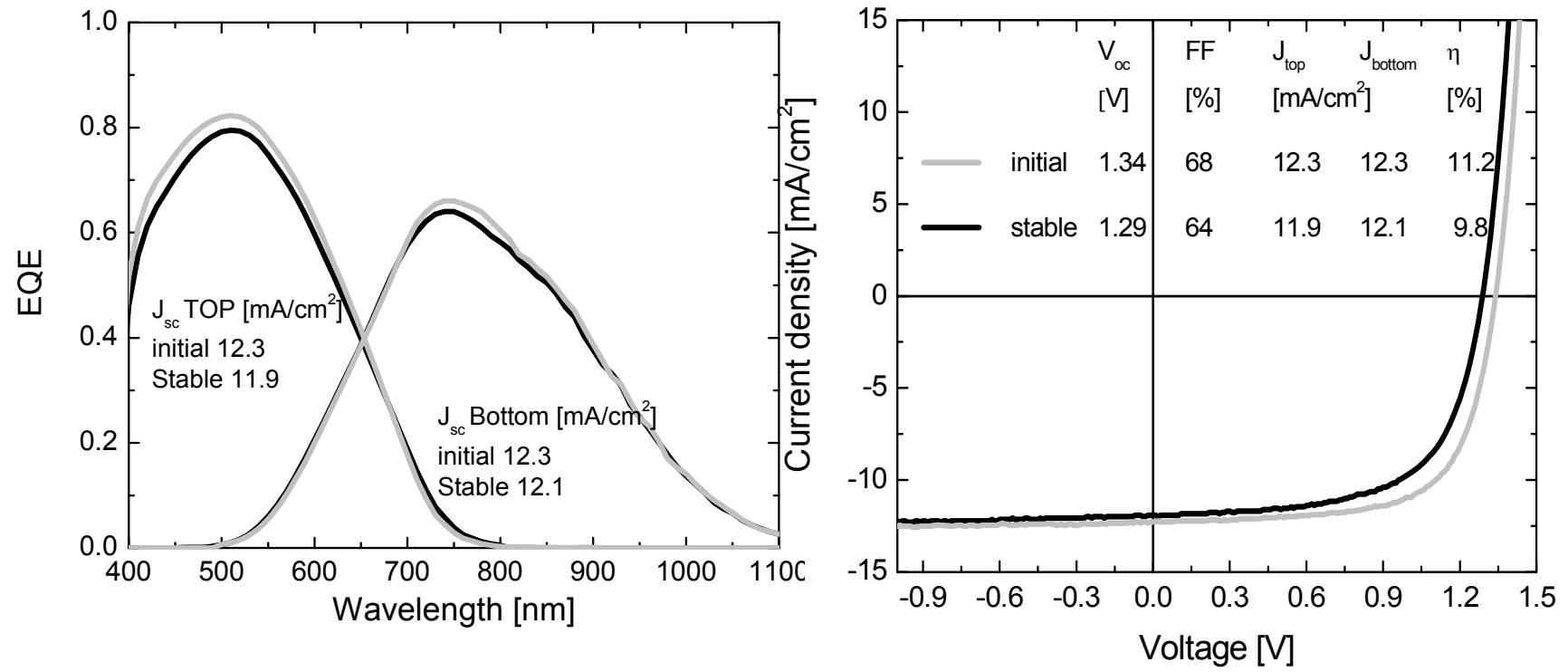

Fig. 15. External quantum efficiency (left) and current voltage characteristic (right) of micromorph tandem cells with AIR on flexible polymer substrate in initial and stabilized state $\left(1000 \mathrm{~h}\right.$ light soak at $50^{\circ} \mathrm{C}$ and an illumination density of $100 \mathrm{~mW} / \mathrm{cm}^{2}$ ) [34].

\section{CONCLUSIONS}

In order to further improve conversion efficiency of thin film silicon photovoltaic devices, multi-junctions such as the micromorph tandem junction have to be developed, and selective light trapping into the thin solar cell is mandatory. The advances in the development of amorphous silicon microcrystalline silicon tandem cells were presented both for the n-i-p and the p-i-n configurations. The development of rough Transparent Conductive Oxide was first shown to allow for improved light scattering at the transmission for $\mathrm{p}$-i-n cells. However, growth of porous material leading to degraded electrical performance of the developed solar cells was also demonstrated on too rough substrates, and specific studies have permitted to determine that typical V-shaped valleys, or pinched surface features, involve growth of this low quality material. Adequate surface treatment of the $\mathrm{ZnO}$ TCOs was shown to smooth the rough surface from $\mathrm{V}$-shaped valleys to U-shaped valleys, and to lead to improved electrical performance while keeping sufficient light scattering. Furthermore, intermediate reflectors were shown to be of paramount importance in micromorph cell between the amorphous top cell and the microcrystalline bottom cell, so as to increase the current density in the top cell and to keep this cell reasonably thin (below $300 \mathrm{~nm}$ ) to allow for low degradation. Intermediate reflectors made of $\mathrm{ZnO}$ or of in-situ deposited silicon nanocrystals embedded in an amorphous matrix of silicon oxide (SOIR) were developed and integrated in micromorph cells. Best results of imicromorph cells developed were reported with up to $13.3 \%$ initial efficiency for small-area reactors and up to $12.3 \%$ initial for large-area industrial reactors. Finally, the different strategies to reach an improved light confinement in a thin film solar cell deposited on a flexible substrate were also discussed. High efficiencies necessitate matched current densities higher than $12.5 \mathrm{~mA} / \mathrm{cm}^{2}$. Currently, an intermediate reflector between the top and bottom cells is the most successful route towards high top cell current densities, but in n-i-p solar cells we observed that the growth of the thick bottom cell results in adverse changes of the surface morphology, resulting in an almost flat interface between the amorphous silicon cell and the microcrystalline cell, limiting the potential of the intermediate 
reflector in these circumstances. By introducing surface texture into the intermediate reflector layer itself, we were able to supply to the top cell its very own light scattering interface, and we are at liberty to use a structure that is experimentally well proven for this purpose. We are able, on plastic substrate to apply that scheme to reach close to $10 \%$ stable efficiency micromorph cell, with an initial matched current of $12.3 \mathrm{~mA} / \mathrm{cm}^{2}$.

\section{ACKNOWLEDGEMENTS}

Funding by the EU projects Flexcellence (contract No. 019948) and Athlet (contract No. 019670) as well as support from the Swiss Federal Office for Energy (OFEN) under project No. 101191 are thankfully acknowledged.

\section{REFERENCES}

[1] Photon-International, “Cell production hits 7.9 GW”, vol. 3 (2009).

[2] First-Solar, http://www.firstsolar.com/

[3] Fthenakis V., Gualtero S., van der Meulen and Kim H.C., Proc. Mater. Res. Soc. Symp. 1041, (2007)

[4] Meier J., Kroll U., Benagli S., et al., "Latest R\&D developments of thin film silicon PV at Oerlikon Solar", Proc. Of the $23^{\text {rd }}$ European Photovoltaic Solar Energy Conference, Valencia (2008).

[5] Kadam A., Li L., Cheng S., et al, "Development of highly efficient a-Si:H/ $\mu \mathrm{C}-\mathrm{Si}: \mathrm{H}$ tandem thin film solar cells on $5.7 \mathrm{~m} 2$ size glass substrates", Proc. Of the $23^{\text {rd }}$ European Photovoltaic Solar Energy Conference, Valencia (2008).

[6] Staebler D., Wronski C. "Reversible conductivity changes in discharge-produced amorphous Si". Applied physics letters vol. 31, p. 292, (1977).

[7] Meier J., Spitznagel J., Kroll U., Bucher C., Fay S., Moriarty T. and Shah A., "High Efficiency amorphous and Micromorph silicon solar cells", Proc. Of the $3^{\text {rd }}$ World Conf. Osaka, 2801-2805 (2003).

[8] Mai Y., Klein S., Wolff J., Lambertz A., Geng X. and Finger F., "Microcrystalline silicon solar cells deposited at high rates by combination for VHF-PECVD and high working pressure", Proc. Of the $19^{\text {th }}$ European Photovoltaic Solar Energy Conference, Paris, 1399 (2004).

[9] Bailat J., Dominé D., Schluchter R., Steinhauser J., et al., "High-efficiency P-I-N microcrystalline and micromorph thin film silicon solar cells deposited on LPCVD ZnO coated glass susbtrates", Proc. Of the $4^{\text {th }}$ WCPEC, Hawaii, 1533-1536, (2006).

[10] Meier J., Torres P., Platz R., et al., "On the way towards high efficiency thin film silicon solar cells by the micromorph concept”, Mat. Res. Soc. Symp. Proc., Spring meeting, San Francisco, 3-14 (1996).

[11] Yoshimi M., Sasaki T., Sawada T., et al., "High efficiency thin film silicon hybrid solar cell module on $1 \mathrm{~m} 2$-class large area substrate", Conference record, $3^{\text {rd }}$ WCPEC, Osaka, 1566-1569, (2003).

[12] Curtins H., Wyrsch N., Favre M., and Shah A., "Influence of plasma Excitation Frequency for a-Si:H Thin Film Deposition", Plasma Chem. Plasma Process., 7, 367, (1987).C. Jones (private communication).

[13] Deckman H. W., Wronski C. R., Witzke H., and Yablonovitch E., Optically Enhanced Amorphous-Silicon SolarCells. Applied Physics Letters, 42 (11): p. 968-970, (1983).

[14] Banerjee A. and Guha S., "Study of Back Reflectors for Amorphous-Silicon Alloy Solar-Cell Application". Journal of Applied Physics, 69 (2): p. 1030-1035, (1991).

[15] Muller J., Rech B., Springer J. and Vanecek M., "TCO and light trapping in silicon thin film solar cells", Sol. Energ. 77, 917, (2004).

[16] Fay S., Kroll U., Bucher C., Vallat-Sauvain E. and Shah A., "Low-pressure chemical vapour deposition of $\mathrm{ZnO}$ layers for thin-film solar cells: temperature induced morphological changes”, Sol. Energ. Mater. Sol. Cells 86, 385, (2005).

[17] Fay S., Steinhauser J., Oliveira N., Vallat-Sauvain E. and Ballif C., "Opto-electronic properties of rough LP-CVD $\mathrm{ZnO}: \mathrm{B}$ for use as TCO in thin-film silicon solar cells". Thin Solid Films, 515 (24): p. 8558-8561, (2007).

[18] Benagli S., Hoetzel J., Borrello D., "High performance LPCVD-ZnO TCO used in P-I-N Amorphous silicon and Micromorph tandem devices", Proc. of the $23^{\text {rd }}$ European Photovoltaic Solar Energy Conference, Valencia (2008).

[19] Shah A., Vanecek M., Meier J., et al, “”, J. Non-Cryst. Solid. 338-340, p. 639, (2004).

[20] Carniglia C. K., "Scalar scattering theory for multilayer optical coatings", Optical Engineering, 18(2): p. 104-115, (1979). 
[21] Zeman M., Van Swaaij R., Metselaar J. W., and Schropp R. E. I., “Optical modeling of a-Si: H solar cells with rough interfaces: Effect of back contact and interface roughness". Journal of Applied Physics, 88: p. 6436, (2000).

[22] Stiebig H., Brammer T., Repmann T., Kluth O., Senoussaoui N., Lambertz A. and Wagner H., "Light Scattering in Microcrystalline Silicon Thin Film Solar Cells", Proc. 16th EU-PVSEC, Glasgow. p. 549-552, (2000).

[23] Domine D., Buehlmann P., Bailat J., Billet A., Feltrin A., and Ballif C., "Optical management in high-efficiency thin-film silicon micromorph solar cells with a silicon oxide based intermediate reflector", Physica Status Solidi (RRL)-Rapid Research Letters, 2(4), (2008).

[24] Python M., Vallat-Sauvain E., Bailat J., Dominé D., Fesquet L., Shah A., and Ballif C., "Relation between substrate surface morphology and microcrystalline silicon solar cell performance". Journal of Non-Crystalline Solids, 354(1925): p. 2258-2262, (2008).

[25] Li H., Franken R., Rath J., and Schropp R., "Structural defects caused by a rough substrate and their influence on the performance of hydrogenated nano-crystalline silicon $n-i-p$ solar cells". Solar Energy Materials and Solar Cells, (2009).

[26] Loffler J., Gordjin A., Stolk R.L., Li H., Rath J. K., Schropp R.E.I, ”Amorphous and micromorph silicon tandem cell with high open-circuit voltage", Solar energy materials and solar cells 87, 251-259, (2005).

[27] Nasuno Y., Kondo M., Matsuda A., "Effects of substrate surface morphology on microcrystalline silicon solar cells", Japanese Journal of Applied Physics 40, 303-305, (2001).

[28] Despeisse M., Anelli G., Jarron P., Kaplon J., Moraes D., Nardulli A., Powolny F., Wyrsch N., "Hydrogenated amorphous silicon sensor deposited on integrated circuit for radiation detection", Transactions on Nuclear Science $55,802-811,(2008)$.

[29] Domine D., "The role of front electrodes and intermediate reflectors in the optoelectronic properties of highefficiency micromorph solar cells", PhD Thesis, University of Neuchatel, 2009

[30] Fischer D., Dubail S., Anna Selvan J. A., et al., "The Micromorph Solar Cell: Extending a-Si:H Technology towards Thin Film Crystalline Silicon", Proceedings of the 25th IEEE Photovoltaic Specialists Conference, Washington D.C., pp. 1053-1056, (1996).

[31] Buehlmann P., Bailat J., Domine D., Billet A., Meillaud F., Feltrin A., and Ballif C., "In situ silicon oxide based intermediate reflector for thin-film silicon micromorph solar cells". Applied Physics Letters, 91(14): p. 143505, (2007).

[32] Yamamoto K., Nakajima A., Yoshimi M., Sawada T., Fukuda S., Suezaki T., Ichikawa M., Koi Y., Goto M., and Meguro T., "A high efficiency thin film silicon solar cell and module”. Solar Energy, 77(6): p. 939-949, (2004).

[33] Haug F.-J., Söderström T., Python M., Terrazzoni-Daudrix V., Niquille X., and Ballif C., "Development of micromorph tandem solar cells on flexible low cost plastic substrates". To be published in Sol. En. Mat., 2009.

[34] Söderström T., "Single and multi-junction thin film silicon solar cells for flexible photovoltaics", PhD Thesis, University of Neuchatel, 2009

[35] Söderström T., Haug F. J., Terrazzoni-Daudrix V., and Ballif C., "Optimization of amorphous silicon thin film solar cells for flexible photovoltaics”. Journal of Applied Physics, 103(11): p. 114509-114509, (2008).

[36] Meier J., Spitznagel J., Kroll U., Bucher C., Faÿ S., Moriarty T., and Shah A., "Potential of amorphous and microcrystalline silicon solar cells". Thin Solid Films, 451: p. 518-524, (2004). 